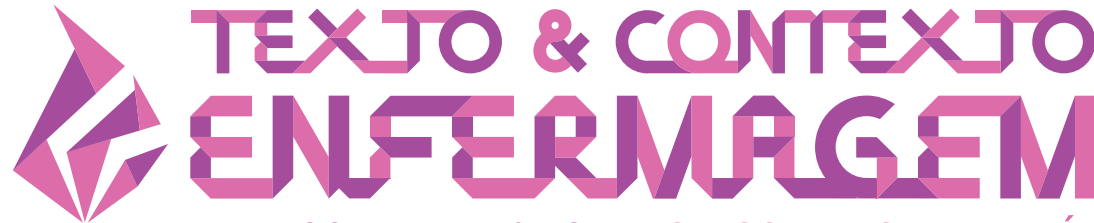

TEXT \& CONTEXT NURSING TEXTO \& CONTEXTO ENFERMERÍA

\section{POWER DEVICES USED BY NURSES TO FIGHT DOMESTIC VIOLENCE AGAINST WOMEN}

\author{
Cristiane Lopes Amarijo' ${ }^{1}$ (D) \\ Camila Daiane Silva ${ }^{1}$ \\ Daniele Ferreira Acosta ${ }^{1}$ (C) \\ Vânia Dias Cruz ${ }^{1}$ \\ Jamila Geri Tomaschewski Barlem ${ }^{1}$ (C) \\ Edison Luiz Devos Barlem ${ }^{1}$ (i)
}

'Universidade Federal do Rio Grande, Escola de Enfermagem. Rio Grande, Rio Grande do Sul, Brasil.

\begin{abstract}
Objective: to identify the power devices used by nurses to fight domestic violence against women from the perspective of parrhesia.

Method: qualitative study addressing 20 nursts from 13 Primary Heath Care units located in Rio Grande, South of Brazil. Interviews were held from April to June 2018, and data were treated using NVIVO 11 under the light of the Discursive Textual Analysis and Foucault's philosophical framework.

Result: two categories emerged from the analysis: (1) knowledge devices and (2) administrative/institutional devices. The first refers to the nurses' actions, such as sharing information concerning domestic violence against women and the second concerns the health units' actions to fight violence and referrals to other sectors focused on providing care to women experiencing domestic violence.

Conclusion: nurses use power devices to support women so they can transform their lives. Nursing can promote social transformations as it is engaged with actions intended to promote health.
\end{abstract}

DESCRIPTORS: Violence against women. Domestic violence. Gender and health. Nursing. 


\section{DISPOSITIVOS DE PODER UTILIZADOS POR ENFERMEIROS PARA O ENFRENTAMENTO DA VIOLÊNCIA DOMÉSTICA CONTRA A MULHER}

\section{RESUMO}

Objetivo: identificar os dispositivos de poder utilizados pelos enfermeiros para o enfrentamento da violência doméstica contra a mulher sob a perspectiva do exercício da parresia.

Método: pesquisa qualitativa realizada com 20 enfermeiros, de 13 Unidades Básicas de Saúde do Município do Rio Grande, extremo Sul do país. Foram entrevistados entre abril e junho de 2018 e os dados tratados pelo software NVIVO $11 \mathrm{sob}$ a luz da Análise Textual Discursiva, bem como, o referencial filosófico foucaultiano.

Resultado: a análise permitiu a geração de duas categorias: (1) dispositivos de saber/conhecimento e (2) dispositivos administrativos/institucionais. A primeira refere-se às ações realizadas pelos enfermeiros, direcionadas para o compartilhamento de informações acerca da violência doméstica contra a mulher. A segunda apresenta a programação das ações de enfrentamento e os encaminhamentos para outros setores engajados na atenção à mulher em situação de violência doméstica.

Conclusão: o enfermeiro faz uso dos dispositivos de poder que tem disponível para auxiliar as mulheres na transformação das situações de violência. A enfermagem pode gerar transformações sociais, uma vez que está engajada em ações que visam à promoção da saúde.

DESCRITORES: Violência contra a mulher. Violência doméstica. Gênero e saúde. Enfermagem.

\section{DISPOSITIVOS DE PODER UTILIZADOS POR ENFERMEROS PARA EL ENFRENTAMIENTO DE LA VIOLENCIA DOMÉSTICA CONTRA LA MUJER}

\section{RESUMEN}

Objetivo: identificar los dispositivos de poder utilizados por los enfermeros para el enfrentamiento de la violencia doméstica contra la mujer bajo la perspectiva del ejercicio de la parresia.

Método: investigación cualitativa realizada con 20 enfermeros, de 13 Unidades Básicas de Salud del Municipio de Rio Grande, en el extremo Sur del país. Fueron entrevistados entre abril y junio de 2018 y los datos tratados por el software NVIVO 11 bajo la luz del Análisis Textual Discursivo, así como el referencial filosófico Foucaultiano.

Resultado: el análisis permitió la generación de dos categorías: (1) dispositivos de saber/conocimiento y (2) dispositivos administrativos/institucionales. La primera se refiere a las acciones realizadas por los enfermeros, dirigidas a compartir informaciones acerca de la violencia doméstica contra la mujer. La segunda presenta la programación de las acciones de enfrentamiento y los encaminamientos para otros sectores comprometidos con la atención a la mujer, en situación de violencia doméstica.

Conclusión: el enfermero utiliza los dispositivos de poder que tiene disponibles para auxiliar a las mujeres en la transformación de las situaciones de violencia. La enfermería puede generar transformaciones sociales, ya que está comprometida con acciones que objetivan la promoción de la salud.

DESCRIPTORES: Violencia contra la mujer. Violencia doméstica. Género y salud. Enfermería. 


\section{INTRODUCTION}

Domestic Violence Against Women (DVAW) refers to unequal manifestations of power between men and women, ${ }^{1}$ resulting from education perpetuated over the centuries by a patriarchal society. ${ }^{2}$

The social distinction between sexes results in an apparent need for women to be obedient to men and men exercising power over women. ${ }^{1}$ In the private sphere, this gender-based inequality legitimates relationship and power standards, making the home, a place that should be considered a reference for haven, safety, and protection, a place where violence is perpetrated and concealed. ${ }^{3}$

Power is not something one has or does not have, nor is it physically placed on a specific locus of the social body or a material good that belongs to someone. Power is a socio-historical construct one can only exercise and only exist in action, perpetuating power relations. Exercising power means acting upon someone else's actions without asking for consent, without renouncing freedom, or transferring rights. It is a way to make others act in the way one desires with a given purpose. ${ }^{4}$

Power operates in a continuous chain in which all individuals can exercise power and bear its effects. ${ }^{5}$ Some of the goals of those exercising power consist of keeping privileges, maintain authority, or a given role. ${ }^{6}$ When thinking about DVAW from the perspective of power relations, it becomes clear that the forms of subordination to which women are subject are devices partners/spouses use to maintain their power focused on continuous aggressive behavior. ${ }^{6}$

A device consists of a set of heterogeneous connected elements, developed from a strategic objective. It may be presented as a speech, institutions, laws, scientific statements, moral propositions, what is said and what is not said, knowledge, truth, rules, etc. ${ }^{7}$ According to the purpose one wants to achieve, these elements can be replaced, excluded, or reconnected to the extent to which they present positive or negative results. Therefore, a device is a strategy, a rational intervention, that is, "It is about the manipulation of power relations [...], either to develop toward a certain direction, to block them, to stabilize them, or use them, etc."7:246

Regarding health workers, power is consolidated when it is associated with technical-scientific knowledge. One study shows that, in health care relationships, nurses assume the commitment to make orders, follow prescriptions, and implement treatment and rehabilitation actions intended to heal, ${ }^{8}$ It is, however, necessary to keep a dialogue with others, enabling people to reflect and manifest their opinions regarding the 'orders' coming from workers.

Thus, the use of parrhesia, a power device that nurses can use, stands out. Parrhesia consists of having the courage to telling the truth, expose opinions, and speak candidly. Those adopting parrhesia are called parrhesiastes and are committed to telling the truth. This parrhesiastic game involves the parrhesiastes and his/her interlocutor, possibly consisting of advice regarding how the interlocutor should think or act. ${ }^{9}$ Therefore, parrhesia is a means through which nurses can positively impact the lives of others.

When facing domestic violence against women, nurses can act as a parrhesiastes from the time they reception women, orient, assist, and encourage them to change their contexts. However, if women do not accept the professional's actions as parrhesiastes, they may avoid returning to the service either for not having the courage to proceed with legal actions to break the violence cycle or for not considering the situation to be violent. The latter may occur because violence has a sociohistorical nature so that some behaviors are naturalized in the context of a couple's relationship.

Nurses are believed to exercise power over women seeking care in Primary Health Care units because they influence people through care actions. Thus, this study's objective was to identify power devices used by nurses to deal with domestic violence against women from the parrhesia perspective. 


\section{METHOD}

This qualitative, descriptive, and analytical study was conducted in 13 Primary Health Care units located in the south of Brazil. Nurses selected through a non-probabilistic sampling method composed a convenience sample and participated in the study. The nurses from each of the Primary Health Care units located in Rio Grande were contacted, received clarification about the study objectives, and were invited to participate. The date and time were then scheduled for the interviews. Inclusion criteria were: being a nurse, currently working in a Primary Health Care unit, with at least six months of experience in the function. There were 29 Primary Health Care units in the city, but only 13 were included in this study because the nurses in the remaining units were either unavailable or did not meet the inclusion criteria. Exclusion criteria were: workers from other fields, nursing technicians, not having at least six months of experience in the function, not being available or being on any kind of leave or vacation). There was more than one nurse in some of these units so that 20 participants met the inclusion criteria.

Data were collected between April and June 2018 through semi-structured interviews recorded and transcribed verbatim and later inserted in NVIVO, version 11.

The Discursive Textual Analysis ${ }^{10}$ and Foucault's philosophical framework were used to treat data. The interview's script included questions that addressed domestic violence against women to identify the use of power devices among nurses. Questions asked whether actions focused on the fight and eradication of violence and, if yes, what these actions were. Three violent scenarios created for this study were also presented. The first presented a woman who experienced psychological violence; in the second, a woman reported physical violence but did not present any bruises; and in the third scenario, a woman presented evidence of aggression. This approach was intended to highlight the type of assistance nurses provided to women in domestic violence situations.

One of the authors, a doctoral candidate at the Federal University of Rio Grande at the time, held all the interviews in a private room in the health units' premises, away from noise and interferences. The interviews lasted $28 \mathrm{~min}$ on average. To ensure the confidentiality of the participants' identities and information, their reports are identified by capital letter $\mathrm{N}$, which corresponded to their profession, followed by a number concerning the interview sequence.

After adding the interviews' content in NVIVO, the Discursive Textual Analysis steps were developed within the software environment. This analysis methodology is composed of three stages: unitization or disassembly of reports, categorization or establishment of relationships, and finally, apprehension of the new emergent discourse..$^{10}$

Researchers examined the material that composed the corpus in detail and fragmented it to compose constituent units in the unitization stage. The excerpts were fragmented, cut, deconstructed, and separated into units of meaning. ${ }^{10}$ Hence, each of the interviews went through the unitization process to identify the nurses' power devices to deal with violence. Each device became a fragment.

The second stage, categorization, is intended to establish relationships between the units identified in the previous stage to compose more complex sets with common elements. At this point, similar meanings are connected, that is, are categorized..$^{10}$ Hence, a connection is established among the fragments that emerged in the first stage to form categories.

The third stage, apprehension of the newly emerging discourse, is achieved after the material is deconstructed and the metatext is reconstructed in an attempt to present an understanding of the combinations established in the previous steps; that is, a new understanding is validated and presented. The metatext enables achieving a new understanding regarding the phenomenon under study. ${ }^{10}$ The categories that emerged from the fragments enabled the new emergent discourse. The results are presented below. 


\section{RESULTS}

The results show that to fight violence, the workers in PHC units are the first to welcome women who experience domestic violence, and nurses adopted a set of actions, technology, and devices to exercise power with this purpose, actions that are close to parrhesia. Hence, two analytical categories emerged from the interviews' analysis: (1) knowledge devices and (2) administrative/ institutional devices.

\section{Knowledge devices}

This category refers to actions intended to welcome women and share the knowledge that enables the exercise of parrhesia, disseminating information in groups and lectures or through folders and posters, based on guidance concerning women's rights.

Initially, knowledge is presented when women are welcomed as a device to endow them with information regarding violence, enabling women to access the truth and release themselves from certain social constructs that imprison them in the stereotype of submissive woman, the queen of the house.

First, we listen attentively to complaints, encourage her to make a report, show her that this is an act of violence against women and that, under the Maria da Penha Law, she has the right to be protected. So, we first encourage her, provide support from the health services, and encourage her to report violence (N1).

I guess that first, we need to provide humanized care, so she is assured that the unit will not do anything against her, anything that will expose her. But always showing her rights, the sources from where she can get support [...] and try to understand what is her support network and identify people who can help, aside from the legal issue, aside from counseling, you know, let her know that health institutions are available to treat this issue of violence (N4).

The importance of the actions performed within the PHC units and the influence of nurses on the lives of women experiencing intimate partner violence becomes apparent. The time when groups are gathered is propitious to address DVAW and to encourage parrhesia-driven actions.

We are here to let her know that she can. Here at the unit, we have a group working with handcrafting, driving lessons, occupation, and income. We have a Human Rights Commission here and people are always providing their support [...] I guess that all we have to do is support them and let them know that they can do it. I'm monitoring a case in which her partner is alcoholic and has always treated her with violence [...] she is the result of the work we do here at the unit. She comes and says: 'ah, because I've listened to what you said. It's absolute right, I'm feeling better', so she's overcome her previous situation. She was $100 \%$ financially dependent on him, but now she's already walking with her own legs (N1).

Regardless of the results, nurses use their strength to create conditions for women to exercise power and change their violent contexts. They welcomed and guided these women and their companions, reported the cases, which is mandatory, and followed ethical and legal conduct under their responsibility, even when women refused to accept parrhesia.

There was the case of this old lady married for many years, with children and grandchildren. She was bitten in front of her house and sought the health unit. We provided her care and welcomed her, reported the case using the SINAN form and provided her guidance, and instructed her son to submit a police report. Still, she didn't, even though she reported this was not the first time it happened. I don't know if she didn't act out of fear. I don't understand what happened and why she didn't proceed with it (N3). 
[...] I explained to her all the details of the report and how to get protection. But she never wanted it because she's crazy about him, she's in love with him and never wanted to do anything against him. Now, it seems things got a bit better [...]. So, it seems they are a little better (N16).

Encouraging women to participate in handcraft workshops was also a device used to encourage them to produce their income and entertain and distract them, even if momentarily, from their lives marked by violence.

We have a handcrafting group on Mondays. It can even be a source of income, so they learn to do goods to sell, there are courses [...] we have to offer them opportunities. They start with the simplest one, are invited to come and work with handcrafting, then the group exposes products at the city's handicraft fair, on the unit's events [on commemorative dates]. They get involved and meet people, and things get better (N8).

Look, we have handicraft workshops, a cooking group. We address all topics. We don't have a group specific for this, but violence is a topic that is also addressed (N19).

[...] there are many people who become depressed for not doing anything [...]. Now they are doing handicrafts, knitting, selling their products, and using modeling clay to make goods and sell (N20).

In addition to the groups within the PHC unit, there are other actions intended to fight violence, such as educational measures. These are implemented to empower victimized women and prevent violence. The lectures are not restricted to the PHC unit as the nurses sought other places within the community, performing activities in schools and neighborhood associations.

We use even the waiting room to empower women, to let them know their rights [...] So, the nurses, psychologists, and physical educators from the multi-professional residence teamwork in schools, and even though they are from the School Health Program, they address this topic, health care, self-care, self-preservation, and empowerment (N8).

We have already worked with it and still do, actually. Last year was a little more intense, and this year at the beginning of the school year. It happens here, addressing some subjects in the groups. We have already talked about it in the pregnant (group) but more frequently in the School Health Program, though we haven't worked very often in other groups (N10).

Folders and posters were hung in the waiting room to reach those women, who for some reason do not reveal the violence they experience. Thus, information was transmitted and they could read and visualize it without having to expose their experiences, giving them the time they needed to transform an intention into a report. Based on this information they obtained knowledge concerning different types of violence, as well as the places where women experiencing domestic violence can get assistance.

We received material, and I guess that the State Department sends it, so the Units' Coordinator sends it. The unit has posters showing the Dial Violence Helpline, phone numbers. I always try to hang them in the reception because this is where they usually wait. So, if there is a woman experiencing violence, the poster describes the types of violence. So, it is an educational measure we use (N9).

\section{Administrative and institutional devices}

This category shows the events some nurses promoted within the PHC units celebrating important dates for women issues and referrals to other professionals within the care network directed to women experiencing domestic violence. At these opportunities, aspects that characterize an abusive relationship and what can be done to prevent abusive situations from worsening were addressed.

[...] right now, in March, we are working on the women's day. We address the subject of abusive relationships in the groups, family planning; we work with the EJA students. EJA has many adolescents, adults, and elderly individuals. There were more than 85 people in the audience, so the psychologist addressed abusive relationships, from dating to a more stable couple relationship. 
Things like what are the signs and symptoms of an abusive relationship, so these are prevention strategies. We always work with these (N1).

[...] every year we address themes. We develop a plan of action and one of our plans of action, we had one that concerned International Women's Day and there will be another one on Mother's Day. We are talking about domestic violence, physical and verbal. We had a meeting on Women's Day and the social worker from NASF came and talked about it; she gave a speech and many women opened up and spoke about their current and past experiences [...] (N7).

[...] we do it at certain times of the year, we do it on the family's month, frequently in August, we address this violence issue (N15).

[...] we seek common spaces, for instance, we have a group of physical activity, only that, everyone interacts in this group. There is a psychologist, nutritionist, social worker, nurse, and we have different approaches. So, we address violence, all those issues that involve care (E12).

The support network appeared as an essential device used by nurses to help women to break the violence cycle. One of the nurses referred to the family as a support upon which women can rely to abandon their situations. Another explained s/he would seek support in case a woman wished to separate/divorce from her spouse/partner and report the violence.

I would let her know that there is the Women's Police Station, that she has rights, that there are other types of relationships because sometimes I guess they stay in these relationships because they don't see any other way. They usually reproduce things they've witnessed between their mothers and fathers. A consultation with this person would be to provide guidance, to let her know l'm open to whatever she might need from me, and that l'd be here to help. But mainly, it'd be to provide guidance, [...] see what her conditions are, whether she really has the means to leave her situation if she has family support for this and show the way, legal procedures. (N10).

As much as we know that they often don't want to report it because their situation is bad and it's like 'bad with him, worse without him'... I guess that she will have to consider her safety, what may happen later. So, l'd tell them to report via the 100 Helpline or a Women's Police Station. And mainly would advise her to seek support [...] so she'd get protection and remove him from her life and protect herself because there is no guarantee even after separation, often, for her safety (N11).

\section{DISCUSSION}

Unequal power relations in marital relationships, which culminates in violence against women, significantly impact women's health, affecting their quality of life. ${ }^{11}$ Hence, it is a fact that women experiencing violence more frequently seek health services, especially Primary Health Care services, ${ }^{12}$ which constitutes most of the demand for care in public health care services. ${ }^{3}$

Therefore, this study shows the importance of nurses using power devices to fight DVAW. Power devices can be material or not, be strategies, or a means to achieve a given objective. ${ }^{6}$ The knowledge devices used to promote the exercise of power among women and encourage them to break with the violence cycle include welcoming, health education groups, lectures, and printed media. Additionally, there are administrative and institutional devices, such as the organization of the units' multi-professional and intersectoral actions. Different devices can be adopted simultaneously, or replaced, adapted, included, or excluded according to the desired results. ${ }^{6}$

When nurses are welcoming these women, they use their knowledge to provide tools that will enable them to access the truth. One study conducted with women experiencing violence reports that women are often unaware of their rights and existing support services, resulting in isolation and preventing them from escaping violent relationships. ${ }^{13}$ Parrhesia can be a piece of advice or orientation, and the means used to communicate information are configured as non-material power devices. ${ }^{6}$ 
This is an opportune time for these women to receive guidance and counseling regarding their rights and self-care. ${ }^{12}$ However, parrhesia goes much further; it is translated as a vital time when attentive listening is implemented to the care provided to women, ${ }^{14-15}$ accompanied by empathy and ties of trust, mainly because it is an opportunity that naturally includes longitudinal and holistic care actions. Therefore, the time of welcoming women, which is a techno-assistance device, should involve women in such a way that transforms them into active participants in the process of producing their health, ${ }^{11}$ enabling them to abandon their violent relationships. A device can guide another's behavior and influence someone to act the way one desires. ${ }^{6}$ When nurses share information that concerns domestic violence against women, they endow them with knowledge that supports decision-making.

Reporting violence and encouraging women to report violence by providing guidance regarding support services, giving shelter, and ensuring confidentiality are reported by other studies ${ }^{16}$ and considered the profession's ethical and legal duties. ${ }^{17}$ These actions are implemented even when women refuse to make a formal report as advised by professionals. The discourses, however, show that the workers had trouble understanding these women's positions.

The health groups implemented in the PHC units also constitute knowledge devices because they seek to value intersubjective relationships and promote changes in the lives of women experiencing violence, or even among those who have never experienced violence but attend the meetings to obtain greater wellbeing and health and also benefit from the knowledge shared. Note that the devices influence others to act in a way one desires; however, they are implemented among free individuals, i.e., they have possibilities to change their situations. ${ }^{6}$ In other words, these women can make choices, taking part in the actions promoted by nurses or not.

The theme is addressed in the different contexts within PHC units, and handcrafting is encouraged among victimize women so they can produce income. One of the most significant limitations these women face and which impedes them from leaving their homes is financial dependency. Women report that not having an income prevents them from commuting to a police station because they do not have the means even to pay for a bus ticket. ${ }^{13}$ Evidence shows that when nurses indirectly practice parrhesia using printed devices such as folders and posters, they help women seek the services closest to their homes (NASF, 180 or 190 helplines, etc.).

The lectures in schools or even in the PHC units, in groups, or the printed media hung on the waiting room are all information addressing the subject. However, these means are seldom addressed in the literature, such as how nurses use them in the PHC context. Visual resources cause great impact so that nurses are supposed to organize the health unit by exposing these resources to make the support services known and disseminating the telephone numbers of these services, such as the 180 helpline and the local women's police station, among others.

Assistance provided to women experiencing domestic violence is not restricted to providing treatment to physical aggression injuries. Multi-professional and integrated actions performed within the units are essential to ensure integral care and meet biopsychosocial needs. ${ }^{12}$ Integration among workers and services is vital to deal with a complex problem such as DVAW.

Considering that a device is a set of actions used to obtain a given result, ${ }^{6}$ administrative and institutional devices are found in the units as they promote events on women's and family's commemorative days to debate the topic. Hence, this study's significant contribution consists of showing other ways nurses can work against violence. Primary Health Care is the entrance door for patients and, for this reason, is a fertile ground to discuss the phenomenon with a view to preventing it. In this field, light technologies stand out and are strengthened daily, reinforcing the nurses' educational role and the exercise of parrhesia.

Referrals to the network services constitute another institutional device. The services the nurses reported to support the fight against DVAW include the Military Brigade, Police Stations, and 
NASF. Perhaps the notion that this problem is under the responsibility of public security would lead nurses to consider the police's presence to be essential for the continuity and resolution of cases. The nurses reported the NASF is a critical service in the care provided to the women due to other workers such as psychologists, physical educators, and social workers, who are recognized as the workers best prepared to assist and refer these women to the proper services. ${ }^{18-19}$

The 100 Helpline was also reported as a support service. Note that this service heeds complaints concerning the violation of human rights among children, adolescents, the elderly, vulnerable persons, and others and is not specific for domestic violence against women. The Women's Service Center, known as the 180 Helpline, is the service that should be activated in domestic violence against women. This public utility service operates 24 hours a day, is free of cost, and keeps the victims' information confidential. This service aims to receive reports of violence and instruct women about their rights and refer them to specialized services whenever necessary. ${ }^{20}$

It is essential that nurses know the local existing resources and social institutions that support women in situation of violence. Moreover, it is important to be aware that these services actually work as a network and there is a flow of care to prevent women from becoming hostage of the system. Unfortunately, studies show that services do not work together, which in turn results in women becoming victims again as they have to repeat their reports numerous times. There is also insufficient problemsolving capacity, as workers are not properly prepared to assist these women. ${ }^{21}$

In addition to the secondary network, the family also appears as a device that can support women. People establish interpersonal relationships and construct social networks from birth and throughout life with their families, friends, co-workers, classmates, or people from other institutions, such as health services. These relationships function as a protection factor, positively influencing their lives. ${ }^{13,16}$ The family is the first instance of the social network to be sought whenever an individual faces a problem and is the primary support device to cope with shame and fear of reporting a case of domestic violence.

However, families sometimes provide limited support so that other components in the network need to be sought. ${ }^{13,16}$ Women with a social support network less frequently face domestic violence. ${ }^{3}$ There are, however, some situations in which the families of women dealing with DVAW may restrict or even harm interactions, modifying or removing an individual from her network.

At this point, the support coming from health workers is relevant. For this reason, nurses adopting parrhesia, that is, who dare to speak the truth, provide the best support for these women to transform their lives. In this sense, parrhesia is presented as a tool that enables nurses to exercise power; using devices intended to help women rebalance their lives.

This study's limitations include the restricted territory in which data were collected, the small sample of nurses, and their experience in the health unit.

\section{CONCLUSION}

The nurses working in PHC units used knowledge and administrative and institutional devices. The first refers to how nurses share information with women, and the second is linked to the unit's programs concerning activities intended to fight domestic violence against women and refer them to services within the support network.

The actions developed by the nurses are power devices intended to contribute to the fight against women. These professionals were in the frontline fighting against violence and performing different actions or devices used to this end. Note that nurses work as parrhesiastes when they welcome women, guide, assist, and encourage them to transform their contexts. 
This study's significant contribution refers to the fact that the use of consistent power devices based on technical-scientific knowledge can be a driving force to fight this phenomenon. Additionally, there is the Primary Health Care setting, the units, which is the place to which the community belongs and where nurses can promote transformations using inclusive and participatory actions intended to promote health and prevent violence.

\section{REFERENCES}

1. Lucena KDT, Deininger LSC, Coelho HFC, Monteiro ACC, Vianna RPT, Nascimento JA. Analysis of the cycle of domestic violence against women. J Hum Growth Dev [Internet]. 2016 [cited 2019 Mar 29];26(2):139-46. Available from: https://doi.org/10.7322/jhgd.119238

2. Guimarães MC, Pedroza RLS. Violence against women: problematizing theoretical, philosophical and legal definitions. Psicol Soc [Internet]. 2015 [cited 2019 Jan 10];27(2):256-66. Available from: https://doi.org/10.1590/1807-03102015v27n2p256

3. Lucena KDT, Vianna RPT, Nascimento JA, Campos HFC, Oliveira ECT. Association between domestic violence and women's quality of life. Rev Latino-Am Enfermagem [Internet]. 2017 [cited 2019 Nov 07];25:e2901. Available from: https://doi.org/10.1590/1518-8345.1535.2901

4. Foucault M. AArqueologia do Saber. 7th ed. Rio de Janeiro, RJ(BR): Forense Universitária; 2008.

5. Dias EFP. A constituição da ética do cuidado de si e a prática da parresía em Michel Foucault [dissertation]. Belo Horizonte, MG(BR): Faculdade Jesuíta de Filosofia e Teologia; 2015.

6. Foucault M. O sujeito e o poder. In: Dreyfus H, Rabinow P. Michel Foucault, uma trajetória filosófica. Rio de Janeiro, RJ(BR): Forense Universitária; 1995. p. 229-249.

7. Foucault M. Sobre a história da sexualidade. In: Foucault M. Microfísica do poder. 26th ed. Rio de Janeiro, RJ(BR): Edições Graal; 2008. p. 243-276.

8. Baptista MKS, Santos RM dos, Duarte SJH, Comassetto I, Trezza MCSF. O paciente e as relações de poder-saber cuidar dos profissionais de enfermagem. Esc Anna Nery [Internet]. 2017 [cited 2019 Aug 12];21(4):e20170064. Available from: https://doi.org/10.1590/2177-9465-ean-2017-0064

9. Foucault M. Discourse and Truth: the Problematization of Parrhesia. Chicago (US): University of Chicago Press; 1999.

10. Moraes R, Galiazzi MC. Análise textual discursiva. 3th ed. ljuí, RS(BR): Editora Unijuí; 2016.

11. Rodrigues WFG, Rodrigues RFG, Ferreira FA. Violence against women within a biopsyocial context: a challenge for the nursing professional. Rev Enferm UFPE [Internet]. 2017 [cited 2019 June 15]; 11(4):1752-8. Available from: https://doi.org/10.5205/1981-8963-v11i4a15247p1752-1758-2017

12. Acosta DF, Gomes VLO, Oliveira DC, Marques SC, Gomes GC. Care for women in domestic violence situation: representations of hospital nurses. Rev Eletr Enf [Internet]. 2017 [cited 2019 Mar 11];19:a21. Available from: https://doi.org/10.5216/ree.v19.42471

13. Albuquerque Netto $L$ de, Moura MAV, Queiroz ABA, Leite FMC, Silva GF. Isolation of women in situation of violence by intimate partner: a social network condition. Esc Anna Nery [Internet]. 2017 [cited 2019 May 13];21(1):e20170007. Available from: 10.5935/1414-8145.20170007

14. Freitas RJM, Sousa VB de, Costa TSC, Feitosa RMM, Monteiro ARM, Moura NA de. Atuação dos enfermeiros na identificação e notificação dos casos de violência contra a mulher. HU Revista [Internet]. 2017 [cited 2019 Nov 25];43(2):91-7. Available from: https://doi.org/10.34019/19828047.2017.v43.2585

15. Zuchi CZ, Silva EB, Costa MC, Arboit J, Fontana DGR, Honnef F, et al. Violence against women: conceptions of family health strategy professionals about listening. Rev Min Enferm [Internet]. 2018 [cited 2019 Sept 25];22:e-1085. Available from: https://doi.org/10.5935/1415-2762.20180015 
16. Arboit J, Padoin SMM, Vieira LB, Paula CC, Costa MC, Cortes LF. Health care for women in situations of violence: discoordination of network professionals. Rev Esc Enferm USP [Internet]. 2017 [cited 2019 Jul 21];51:e03207. Available from: https://doi.org/10.1590/S1980-220X2016013603207

17. Acosta DF, Gomes VLO, Oliveira DC, Gomes GC, Fonseca AD. Aspectos éticos e legais no cuidado de enfermagem às vítimas de violência doméstica. Texto Contexto Enferm [Internet]. 2017 [cited 2019 Oct 24];26(3):e6770015. Available from: https://doi.org/10.1590/0104-07072017006770015

18. Ministério da Saúde (Brasil). Núcleo de Apoio à Saúde da Família (NASF). Departamento de Atenção Básica; 2018 [cited 2018 Oct 12]. Available from: http://dab.saude.gov.br/portaldab/ nasf_perguntas_frequentes.php

19. Pereira-gomes N, Erdmann AL, Rebouças-Gomes N, Silva-Monteiro D, Santos RM, MenezesCouto T. Social support to women in situation of domestic violence. Rev Salud Pública [Internet]. 2015 [cited 2019 Feb 02];17(6):823-35. Available from: https://doi.org/10.15446/rsap.v17n6.36022

20. Ministério da Mulher, da Família e dos Direitos Humanos (Brasil). Disque 100; 2019 [cited 2019 Dec 17]. Available from: https://www.mdh.gov.br/informacao-ao-cidadao/disque-100-1

21. Santos WJ, Freitas MIF. Weaknesses and potencialities of the healthcare network for women in situations of intimate partner violence. Rev Min Enferm [Internet]. 2017 [cited 2019 Mar 29];21:e1048. Available from: https://doi.org/10.5935/1415-2762.20170058 


\section{NOTES}

\section{ORIGIN OF THE ARTICLE}

Article extracted from the thesis - O exercício da parrhesia por enfermeiros da atenção básica no cuidado a mulheres em situação de violência doméstica, presented to the Programa de Pós-Graduação, Escola de Enfermagem, Universidade Universidade Federal do Rio Grande, in 2019.

\section{CONTRIBUTION OF AUTHORITY}

Study design: Amarijo CL, Silva CD, Acosta DF, Cruz VD, Barlem JGT, Barlem ELD.

Data collect: Amarijo CL, Silva CD, Acosta DF.

Data analysis and interpretation: Amarijo CL, Silva CD, Acosta DF.

Discussion of the results: Amarijo CL, Silva CD, Acosta DF, Cruz VD, Barlem JGT, Barlem ELD.

Writing and / or critical review of content: Amarijo CL, Silva CD, Acosta DF, Cruz VD, Barlem JGT.

Review and final approval of the final version: Amarijo CL, Silva CD, Acosta DF, Cruz VD.

\section{FUNDING INFORMATION}

This study was financed by the Coordenação de Aperfeiçoamento de Pessoal de Nível Superior Brazil (CAPES) - Finance Code 001.

\section{APPROVAL OF ETHICS COMMITTEE IN RESEARCH}

Approved by the Ethics Committee in Research with Human Beings of the Universidade Federal de Rio Grande opiniom n 36/2018 e C.A.A.E: 81965918.5.000.5324.

\section{CONFLICT OF INTEREST}

There is no conflict of interest.

\section{EDITORS}

Associated Editors: Selma Regina de Andrade, Gisele Cristina Manfrini, Melissa Orlandi Honório Locks, Monica Motta Lino

Editor-in-chief: Roberta Costa

\section{HISTORICAL}

Received: February 08, 2020

Approved: April 16. 2020

\section{CORRESPONDING AUTHOR}

Cristiane Lopes Amarijo

cristianeamarijo@yahoo.com.br 